\title{
Artikel Review
}

\section{Ekspresi Annexin A2 pada Kanker Ginekologi: Sebuah Tinjauan Sistematis}

\author{
William Alexander Setiawan \\ Departemen Obstetri dan Ginekologi Fakultas Kedokteran Universitas Udayana/ \\ RSUP Sanglah, Denpasar Bali \\ Korespondensi: William Alexander Setiawan Email: William.alexanders11@gmail.com
}

\begin{abstract}
Abstrak
Tujuan: Untuk menentukan adanya hubungan antara ekspresi ANXA2 dan berbagai aspek kanker ginekologi. Metode: Pencarian terstruktur untuk penelitian yang menyelidiki hubungan ekspresi ANXA2 dan kanker serviks, kanker endometrium dan kanker ovarium menggunakan PubMed. Pencarian terbatas pada 10 tahun terakhir dan dilakukan penyaringan dengan kriteria inklusi serta eksklusi yang telah ditetapkan.

Hasil: Dari 52 penelitian didapatkan 9 penelitian yang kemudian dilakukan telaah kritis. ANXA2 diekspresikan berlebih dalam jaringan karsinoma dibandingkan dengan jaringan normal.

Kesimpulan: Peningkatan ekspresi ANXA2 berperan dalam proliferasi sel kanker. Ekspresi ANXA2 berkorelasi dengan stadium lanjut dan penyakit metastasis. ANXA2 dapat digunakan untuk memprediksi progresivitas, angka kelangsungan hidup, dan resistensi terhadap rejimen pengobatan.
\end{abstract}

Kata kunci: Annexin A2, kanker ginekologi, proliferasi

\section{Annexin A2 Expression in Gynecological Cancer: A Systematic Review}

\author{
Abstract \\ Objective: To determine the relationship between ANXA2 expression and various aspects of gynecological cancer. \\ Method: A structured search for studies involving the relationship of ANXA2 and cervical cancer, endometrial \\ cancer and ovarian cancer using PubMed. Search is limited to the last 10 years and is screened with predetermined \\ inclusion and exclusion criteria. \\ Result: Of the 52 studies obtained 9 studies which were then carried out critical studies. ANXA2 is overexpressed \\ in carcinoma tissue compared to normal tissue. \\ Conclusion: Increased expression of ANXA2 approved in cancer cell proliferation. Expression of ANXA2 \\ correlates with advanced stage and metastatic disease. ANXA2 can be used to predict progression, survival rates, \\ and resistance to treatment regimens.
}

Key words: Annexin A2, gynecological cancer, proliferation 


\section{Pendahuluan}

Uji klinis dan penilaian prognosis sangat penting untuk perawatan kanker. ${ }^{1}$ Deteksi penanda molekuler spesifik berperan penting dalam proses ini. Meskipun ada kemajuan dalam pengobatan kanker, hasil yang diberikan secara substansial belum meningkat. Hal ini menekankan perlunya deteksi dini dan penanda prognostik dalam memperbaiki strategi pengobatan.

Karakteristik patologi klinis saat ini, seperti ukuran tumor, stadium, derajat dan invasi, tidak sepenuhnya meningkatkan prognosis klinis, oleh karena itu, diperlukan prediktor yang lebih baik. Annexin adalah protein intraseluler yang bersifat calciumdependent dan mengikat membran tinggi protein di intraseluler.

Annexin A2 (ANXA2) adalah protein multifungsional yang terlibat dalam proliferasi sel, fisiologi membran dan berpartisipasi dalam invasi tumor, metastasis dan angiogenesis. Tingkat ekspresi ANXA2 berkorelasikan dengan banyak jenis keganasan. Peningkatan regulasi ANXA2 terkait mutasi gen sel kanker, termasuk kanker serviks, kanker endometrium dan kanker ovarium telah terbukti berkorelasi dengan berbagai parameter klinis dan prognosis yang buruk..$^{2-10}$

Tinjauan sistematis ini dilakukan untuk menjelaskan signifikansi prognostik ekspresi ANXA2 dalam kelangsungan hidup pasien kanker ginekologi.

\section{Metode}

Dilakukan pencarian awal dalam basis data PubMed.

Pencarian menggunakan kata kunci

(1) "Annexin A2" dan "kanker serviks",

(2) “Annexin A2" dan "kanker endometrium",

(3) “AnnexinA2" dan "kankerovarium"dalam

\section{Bahasa Inggris.}

Pencarian terbatas pada naskah lengkap yang diterbitkan dalam bahasa Inggris 10 tahun terakhir. Referensi yang dicantumkan termasuk semua artikel dan ulasan terkait juga meta-analisis. Untuk penyaringan awal artikel, semua judul dan abstrak dibaca.

Kriteria inklusi pada penelitian ini adalah: (1) Ekspresi ANXA2 dinilai dengan immunohistochemistry (IHC), (2) Evaluasi nilai prognostik ekspresi ANXA2 pada angka kelangsungan hidup atau parameter patologi klinis, (3) Artikel ditulis dalam Bahasa Inggris, (4) Artikel terbit dalam 10 tahun terakhir.

Kriteria eksklusi pada penelitian ini adalah: (1) Artikel merupakan ulasan, editorial atau surat, (2) Kurangnya informasi saat pengambilan data seperti $95 \%$ confidence interval (CI) atau odds ratio (OR), (3) Artikel bukan dilakukan pada manusia.

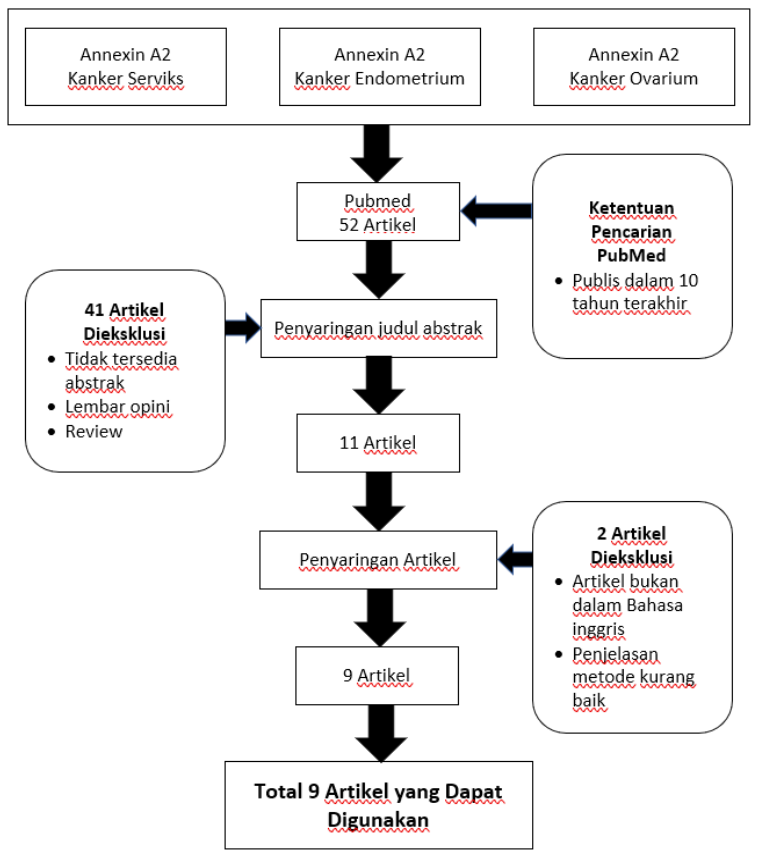

Gambar 1 Diagram Hasil Pencarian Sumber Data

\section{Hasil}


Dari total keseluruhan 52 artikel didapatkan 9 penelitian yang mengevaluasi peran ANXA2 pada kanker ginekologis. tiga penelitian mengevaluasi hubungan ANXA2 dan kanker serviks, ${ }^{2-4}$ dua penelitian mengevaluasi hubungan dengan kanker endometrium ${ }^{5,6}$ dan empat penelitian mengevaluasi hubungan dengan kanker ovarium. ${ }^{7-10}$

Kanker serviks. Ekspresi abnormal protein ANXA2 dan S100A telah dilaporkan menginduksi resistensi terhadap kemoterapi cisplatin di antara pasien kanker serviks. Analisis IHC menunjukkan peningkatan ekspresi ANXA2 dalam sel stroma serviks setelah menjalani kemoterapi.

Selain itu, ekspresi ANXA2 secara signifikan lebih tinggi pada kelompok tumor yang tidak memberikan respon terhadap kemoterapi. Hal ini menunjukkan bahwa peningkatan regulasi ANXA2 dapat berperan pada resistensi terhadap kemoterapi.

Lebih lanjut, ekspresi ANXA2 dalam sel stroma kanker serviks adalah faktor prognostik independen untuk penurunan progresi angka kelangsungan hidup. ${ }^{2,3}$ ANXA2 terbukti berkorelasi positif dengan kanker stadium lanjut, menunjukkan hubungan ekspresi ANXA2 dengan stadium kanker yang lebih tinggi. ${ }^{3}$

$$
\text { Human papillomaviruses (HPV) }
$$
adalah virus yang ditularkan secara seksual yang secara kausal berhubungan dengan perkembangan kanker serviks. HPV16 adalah virus intraseluler yang masuk ke dalam sel inang untuk bertahan hidup. ${ }^{4}$ Internalisasi HPV16 ini sebagian difasilitasi oleh heterotetramer ANXA2-S100A10. Dengan menghambat ANXA2 secara endogen atau dengan antibodi anti-ANXA2, internalisasi HPV16 menurun secara signifikan.

Kanker endometrium. ANXA2 diekspresikan pada membran dan sitoplasma sel kanker endometrium pada 95,2\% kasus dibandingkan dengan 55,6\% pada endometrium normal. ${ }^{5}$ Studi in vitro menunjukkan ANXA2 dapat berperan dalam mempromosikan metastasis pada kanker endometrium. Penurunan ekspresi ANXA2 mengakibatkan tidak adanya metastasis ke paru dan hematogen, ${ }^{6}$ menyiratkan ANXA2 memainkan peranan dalam pengembangan metastasis jauh. Ditemukan ekspresi ANXA2 yang tinggi pada $91,7 \%$ pasien karsinoma endometrium stadium III-IV. Ekspresi ANXA2 secara signifikan lebih tinggi dibandingkan pasien pada stadium I-II dengan 55\% $(\mathrm{P}<0,05)$.

Ekspresi berlebih ANXA2 berkorelasi dengan angka kelangsungan hidup yang lebih pendek. ${ }^{5}$ Hal ini menunjukkan bahwa ANXA2 dapat menjadi fokus terapi potensial untuk menghindari penyebaran kanker endometrium dan untuk memprediksi kekambuhan serta angka kelangsungan hidup.

Kanker ovarium. ANXA2 diekspresikan dalam membran dan sitoplasma dari sel serosa serta sel stroma sekitarnya. Dilaporkan ekspresi ANXA2 dalam klasifikasi FIGO stadium IV dibandingkan dengan stadium II dan III. ${ }^{7}$ Ekspresi ANXA2 terkait dengan histological grade, selain itu, peningkatan signifikan ekspresi ANXA2 juga terkait dengan adanya asites dan sel maligna dalam cairan peritoneum. ${ }^{8}$ Penurunan ekspresi ANXA2 dalam sel kanker ovarium secara signifikan mengurangi kemampuan invasi dan migrasi.

Ekspresi stroma yang tinggi secara signifikan mengakibatkan penurunan angka bebas progresi dan penurunan angka kelangsungan hidup. Pasien dengan ekspresi ANXA2 stroma yang tinggi memiliki risiko peningkatan progresi penyakit 1,8 kali lipat dan peningkatan risiko kematian 1,6 kali lipat.

Kombinasi dengan S100A10 akan membuat ekspresi ANXA2 dapat memprediksi efek samping merugikan bagi pasien kanker ovarium. Untuk pasien dengan ekspresi ANXA2 stroma dan sitoplasma S100A10 yang tinggi, angka kelangsungan 
Tabel 1 Karakteristik ANXA2 Pada Kanker Ginekologi

\begin{tabular}{|c|c|c|c|}
\hline $\begin{array}{l}\text { Lokasi } \\
\text { Kanker }\end{array}$ & Peneliti & Manifestasi Klinis & Terapeutik \\
\hline $\begin{array}{l}\text { Kanker } \\
\text { Serviks }\end{array}$ & $\begin{array}{l}\text { Woodham et al. } \\
(2012) \\
\text { Jin et al. } \\
(2012) \\
\text { Choi et al. } \\
\text { (2016) }\end{array}$ & $\begin{array}{ll}\text { - } & \text { Ekpresi ANXA2 meningkat } \\
\text { - } & \text { Resistensi terhadap kemoter- } \\
& \text { api } \\
\text { - } & \text { Kanker stadium lanjut } \\
\text { - } & \text { Penurunan angka kelang- } \\
& \text { sungan hidup } \\
\text { - } & \text { Internalisasi HPV16 }\end{array}$ & $\begin{array}{l}\text { - Pengobatan dengan antibodi anti- } \\
\text { ANXA2 dapat mengurangi angka } \\
\text { kejadian kanker serviks yang diaki- } \\
\text { batkan oleh HPV16 }\end{array}$ \\
\hline $\begin{array}{l}\text { Kanker } \\
\text { Endometrium }\end{array}$ & $\begin{array}{l}\text { Alonso et al. } \\
(2014)\end{array}$ & $\begin{array}{ll}\text { - } & \text { Ekspresi ANXA2 meningkat } \\
\text { - } & \text { Histological grade yang lebih } \\
\text { tinggi } \\
\text { - } & \text { FIGO-stage yang lebih tinggi } \\
\text { - } & \text { Invasi yang lebih dalam } \\
\text { - } & \text { Metastasis kelenjar limfe } \\
\text { - } & \text { Metastasis jauh }\end{array}$ & $\begin{array}{l}\text { - Pendekatan proteomic untuk men- } \\
\text { gidentifikasi ANXA2 sebagai pen- } \\
\text { anda terjadinya rekurensi kanker } \\
\text { endometrium } \\
\text { - ANXA2 daan HE4 dapat digunak- } \\
\text { an sebagai penanda untuk evaluasi } \\
\text { prognosis }\end{array}$ \\
\hline $\begin{array}{l}\text { Kanker } \\
\text { Ovarium }\end{array}$ & $\begin{array}{l}\text { Lokman et al. } \\
(2013) \\
\text { Deng et al. } \\
(2014) \\
\text { Pi et al. } \\
\text { (2016) } \\
\text { Lokman et al. } \\
\text { (2016) }\end{array}$ & $\begin{array}{ll}\text { - } & \text { Ekspresi ANXA2 meniggkat } \\
\text { - } & \text { Diferensiasi yang buruk } \\
\text { - } & \text { Asites } \\
\text { - } & \text { Sel maligna dalam cairan } \\
& \text { peritoneum } \\
\text { - } & \text { Invasi dan migrasi } \\
\text { - } & \text { Metastasis } \\
\text { - } & \text { Progresi } \\
\text { - } & \text { Penurunan angka kelangsun- } \\
& \text { gan hidup }\end{array}$ & 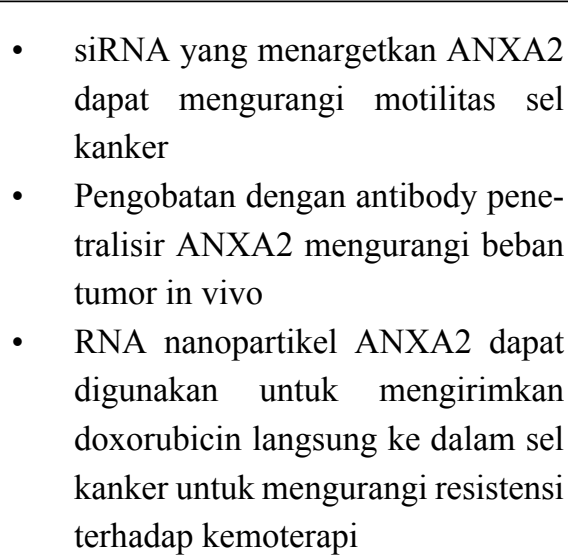 \\
\hline
\end{tabular}

hidup adalah 11,1\% dibandingkan dengan ekspresi ANXA2 stroma dan sitoplasma S100A10 yang rendah sebesar 50\%. ${ }^{7}$

Sirkuit RNA yang menargetkan ANXA2 secara signifikan menurunkan motilitas dan invasi pada sel kanker ovarium. Studi in vivo pada tikus menunjukkan bagaimana pengobatan dengan antibodi penetral ANXA2 secara signifikan mengurangi tumor. ${ }^{9}$ Hal ini membuat sirkuit RNA menargetkan antibodi penetral ANXA2 dan ANXA2 sebagai fokus terapi potensial untuk pengobatan kanker ovarium. Studi lain menunjukkan bahwa nanopartikel RNA yang menyimpan ANXA2 dapat digunakan untuk mengirimkan doxorubicin ke dalam sel kanker. Pengetahuan tentang mekanisme ini dapat membantu mengatasi kanker ovarium yang resisten terhadap kemoterapi dan untuk meminimalkan efek samping kemoterapi pada jaringan yang sehat. ${ }^{10}$

\section{Pembahasan}

Mekanisme pengaruh dan peran ANXA2 dalam berbagai jenis kanker ginekologi masih 
Tabel 2 Rekapitulasi Manifestasi Klinis Peningkatan Ekspresi Anxa2 Pada Kanker Ginekologi

\begin{tabular}{lccc}
\hline \multicolumn{1}{c}{ Manifertasi Klinis } & $\begin{array}{c}\text { Kanker } \\
\text { Serviks }\end{array}$ & $\begin{array}{c}\text { Kanker } \\
\text { Endometrium }\end{array}$ & $\begin{array}{c}\text { Kanker } \\
\text { Ovarium }\end{array}$ \\
\hline Resistensi terhadap kemoterapi & $\sqrt{ }$ & $\sqrt{ }$ & \\
T-stage & & $\sqrt{ }$ & $\sqrt{ }$ \\
N-stage & & $\sqrt{ }$ & $\sqrt{ }$ \\
M-stage & & $\sqrt{ }$ & $\sqrt{ }$ \\
Histological grade & & $\sqrt{ }$ \\
Penurunan angka kelangsungan hidup & & & $\sqrt{ }$ \\
\hline
\end{tabular}

belum jelas. Tabel 2 merangkum manifestasi klinis korelasi antara peningkatan ekspresi ANXA2 dan kanker ginekologi. Secara umum tampak peningkatan ekspresi ANXA2 merupakan fenomena dominan yang dapat dikorelasikan dengan luaran klinis buruk.

Annexin berkolaborasi dengan protein yang berbeda seperti plasminogen, S100A10 dan HE4. Interaksi yang kompleks antara agen tersebut dengan ANXA2 berperan dalam potensi keganasan. Regulasi dan kolaborasi ANXA2 yang sedang berlangsung menjadi fondasi bagi potensi keganasan dan menjadi fokus untuk investigasi lebih lanjut pada penargetan terapi.

Semua studi yang terdaftar dalam tinjauan ini menggunakan IHC yang memberi mereka beberapa batasan. Tingkat pewarnaan, konsentrasi antibodi dan nilai batas bisa berbeda di antara penelitian. Ketika membandingkan tingkat pewarnaan ANXA2, ahli patologi membuat klasifikasi tumor secara individual karena belum ada sistem penilaian internasional untuk ANXA2. IHC merupakan instrumen tambahan untuk deskripsi histopatologis. Saat ini, sebagian besar tumor menjalani pewarnaan IHC dengan dikombinasikan antibodi lainnya. Pewarnaan ANXA2 hanya menjadi tambahan ke panel IHC yang digunakan saat ini.

Secara keseluruhan ada sejumlah penelitian yang terbatas pada topik mengenai ekspresi ANXA2 dan tingkat rekurensi kanker atau kemungkinan korelasi antara peningkatan ekspresi ANXA2 dengan resistensi kemoterapi. Terdapat kebutuhan untuk penelitian yang lebih mendalam mengenai jalur dan mekanisme ANXA2 dalam pembentukan tumor. Hal ini menarik, karena potensi ANXA2 sebagai agen terapi dalam pengobatan kanker. Kemampuan siRNA untuk mengganggu ekspresi ANXA2 menarik dalam pengobatan malignansi karena potensinya untuk mengurangi resistensi pengobatan. Ada kebutuhan yang meningkat saat ini untuk menentukan pengobatan kanker secara individu dan menarik untuk memiliki lebih banyak pengetahuan tentang penggunaan antibodi anti-ANXA2 dan siRNA pada sel kanker. Simpulan penelitian ini meninjau kemampuan ekspresi ANXA2 di berbagai sel kanker untuk memprediksi luaran yang merugikan. Ekspresi ANXA2 berkorelasi dengan stadium lanjut dan metastasis penyakit. ANXA2 dapat digunakan untuk memprediksi progresivitas, angka kelangsungan hidup, dan resistensi terhadap rejimen pengobatan. Tinjauan ini membuat garis besar pengaruh ANXA2 terhadap kanker ginekologi. Penelitian ini diharapkan dapat menjadi dasar untuk penelitian lebih lanjut tentang ANXA2 yang mungkin menghasilkan konsensus tentang penggunaan klinis biomarker ini.

\section{Daftar Pustaka}

1. Fukuoka $\mathrm{M}, \mathrm{Wu} \mathrm{YL}$, Thongprasert $\mathrm{S}$, Sunpaweravong P, Leong SS, Sriuranpong $\mathrm{V}$, et al. Biomarker analyses and final 
overall survival results from a phase III, randomized, open-label, firstline study of gefitinib versus carboplatin/ paclitaxel in clinically selected patients with advanced non-small-cell lung cancer in Asia (IPASS). J Clin Oncol. 2011;29(21):2866-74. doi: 10.1200/ JCO.2010.33.4235

2. Jin L, Shen Q, Ding S, Jiang W, Jiang L, Zhu X. Immunohistochemical expression of Annexin A2 and S100A proteins in patients with bulky stage IB-IIA cervical cancer treated with neoadjuvant chemotherapy. Gynecol Oncol. 2012 Jul;126(1):140-6. doi: 10.1016/j. ygyno.2012.04.005

3. Choi CH, Chung JY, Chung EJ, Sears JD, Lee JW, Bae DS, Hewitt SM: Prognostic significance of annexin A2 and annexin A4 expression in patients with cervical cancer. BMC Cancer 16: 448, 2016. doi: 10.1186/s12885-016-2459-y

4. Woodham AW, Da Silva DM, Skeate JG, Raff AB, Ambroso MR, Brand HE, et al. The S100A10 subunit of the annexin A2 heterotetramer facilitates L2-mediated human papillomavirus infection. PLoS One. 2012;7(8): e43519. doi: 10.1371/ journal.pone.0043519

5. Deng L, Gao Y, Li X, Cai M, Wang H, Zhuang $\mathrm{H}$, et al. Expression and clinical significance of annexin A2 and human epididymis protein 4 in endometrial carcinoma. J Exp Clin Cancer Res. 2015 Sep 11;34:96. doi: 10.1186/s13046-0150208-8

6. Alonso-Alconada L, Santacana M, Garcia-Sanz P, Muinelo-Romay L, Colas $\mathrm{E}$, Mirantes $\mathrm{C}$, et al. Annexin-A2 as predictor biomarker of recurrent disease in endometrial cancer. Int J Cancer. 2015 Apr 15;136(8):1863-73. doi: 10.1002/ ijc. 29213

7. Lokman NA, Pyragius CE, Ruszkiewicz A, Oehler MK, Ricciardelli C. Annexin A2 and S100A10 are independent predictors of serous ovarian cancer outcome. Transl Res. 2016 May;171:83-95.e1-2. doi: 10.1016/j.trsl.2016.02.002

8. Deng Y, Chen C, Hua M, Xi Q, Liu R, Yang S. Annexin A2 plays a critical role in epithelial ovarian cancer. Arch Gynecol Obstet. 2015 Jul;292(1):175-82. doi: 10.1007/s00404-014-3598-5

9. Lokman NA, Elder AS, Ween MP, Pyragius CE, Hoffmann P, Oehler MK, et al. Annexin A2 is regulated by ovarian cancer-peritoneal cell interactions and promotes metastasis. oncotarget 4: 1199-1211, 2013. doi: 10.18632/ oncotarget. 1122

10. Pi F, Zhang H, Li H, Thiviyanathan V, Gorenstein DG, Sood AK, et al. RNA nanoparticles harboring annexin A2 aptamer can target ovarian cancer for tumor-specific doxorubicin delivery. Nanomedicine. 2017 Apr;13(3):11831193. doi: 10.1016/j.nano.2016.11.015 